\section{OP-065糖尿病モデルラットにおける膀胱受容体 の変動}

\section{静岡県立大学薬学部医療薬学大講座薬物動態学分野グロー} バル $\mathrm{COE}^{1)}$, 日本大学医学部泌尿器科学講座 ${ }^{21}$

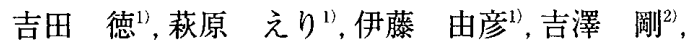

\section{高橋 悟帛, 山田 静雄 ${ }^{1)}$}

【目的】糖尿病に伴う排尿障害を明らかにする目的で、糖尿 病モデルラットにおける膀胱のムスカリン性及びATP 受 容体を測定した。【方法】Wistar 系雌性ラットにストレプト ゾトシン $(\mathrm{STZ}, 50 \mathrm{mg} / \mathrm{kg})$ を単回腹腔内投与し、血漿グ ルコース值が $250 \mathrm{mg} / \mathrm{dl}$ 以上に上昇したラットを実験に用 いた。STZ 投与後 $1 、 4 、 8$ 週間経過したラットの摘出膀胱よ り調製した受容体標品を用い、 $\left[{ }^{3} \mathrm{H}\right] \mathrm{N}$-methylscopolamine (NMS)、 $\left[{ }^{3} \mathrm{H}\right] \alpha \beta-$ methylene ATP $(\alpha \beta-M e A T P)$ を標識り ガンドとするラジオレセプターアッセイによりムスカリン 性及びATP 受容体を測定した。Nonlinear regression 解析 により各リガンドの解離定数 $(\mathrm{Kd})$ 並びに最大結合部位数 （Bmax）を算出した。【結果】(1)STZ 投与ラットの体重は対 照ラットに比べ有意に減少し、膀胱重量は有意に増加した。 (2) STZ 投与ラット膀胱における $\left[{ }^{3} \mathrm{H}\right] \mathrm{NMS}$ 及び $\left.{ }^{3} \mathrm{H}\right] \alpha \beta-$ MeATP 特異的結合の Kd 值は対照ラットの場合と差異が なかったが、単位組織量当りの Bmax 值は有意に増加し た。結論】STZ 投与ラットにおいて膀胱ムスカリン性及び ATP 受容体数の変動が示唆された。

\section{OP-066}

ラット閉塞膀胱作製後アンジオテンシン II タイプ 1 受容体遮断薬カンデサルタン 長期投与の効果

\section{福島県立医科大学医学部泌尿器科学講座}

酒井 多喜夫, 相川 健, 川島 洋平, 塩見 誉,

片岡 政雄, 白岩 学, 松岡 俊光, 櫛田 信博,

柳田 知彦,山口 脩

目的：アンジオテンシン II タイプ1受容体 (ATl)の存在と伸展刺激 による局所のアンジオテンシン II (ANGII) 産生が膀胱平滑筋で報告 されている。我々はラット閉塞膀胱モデル（BOO）を使いAT1 遮断 薬カンデサルタンを長期投与しその効果を検討した。方法：12 週路 の雄 SD ラットに sham 手術あるいは BOO 作製し、2 週後 BOO 作製 ラットに浸透圧ポンプを使いカンデサルタン $(0.2 \mathrm{mg} / \mathrm{kg} / \mathrm{day})$ 、vehicle t 4 週間投与して sham 群、BOO 群、カンデサルタン群で以下の 実験結果を比較した。1.膀腅重量測定後膀胱切片でANGI、神経電気

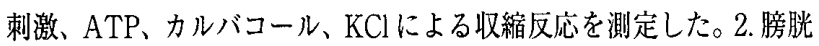
組織をエラスチカーマッソン $(\mathrm{EM})$ 法で染色した。結果：膀胱重量は sham 群 $(212 \pm 53 \mathrm{~g})$ に比べBOO 群 $(546 \pm 430 \mathrm{~g})$ で有意に増加し、カ ンデサルタン群 $(297 \pm 98 \mathrm{~g})$ で抑制された。ANGIIによる収縮反応は カンデサルタン群でみられず、sham 群と BOO 群で差はなかった。そ の他の刺激による収縮反応は sham 群に比べ BOO 群で低下し、ATP 以外の収縮反応はカンデサルタン群で有意に回復した。EM 染色で sham 群に比べ BOO 群で筋線維、膠原線維共に増加し、カンデサル夕 ン群で両者は共に減少した。結論 : 閉塞膀胱の膀胱肥大・線維化に ANGII の関与とカンデサルタンによる改善の可能性が示唆された。

\section{OP-067}

Suppression of bladder oxidative stress and inflammation by a phytotherapeutic agent eviprostat ${ }^{\circledR}$ in rat partial bladder outlet obstruction model

\section{日本新薬 (株) 創薬研究所 \\ 岡 美智子, 福井 智美, 上田 誠, 多賀谷 光洋, 尾山 達哉, 田中 充士}

Ischemia/reperfusion is a major etiological factor in the progression of bladder dysfunction after partial bladder outlet obstruction (BOO), which is partly mediated by the generation of free radicals. The phytotherapeutic agent eviprostat $^{(B)}$ for BPH reported to possess antioxidant and anti-inflammatory activity. The effect of eviprostat ${ }^{\mathbb{R}}$ on oxidative stress and inflammation in the bladder after BOO was investigated. On the $6^{\text {th }}$ day after BOO-operation, a significant increase in bladder weight, oxidative stress markers and proinflammatory cytokine levels were found when compared to those of sham-operated animals. Eviprostat blocked these increase without affecting the bladder weight. Histological analysis showed that suppression of inflammatory changes was associated with evitpsotat treatment. These findings suggest that the reduction of the enhanced oxidative stress and proinflamattory cytokines by BOO may contribute to the improvement of lower urinary tract symptoms in $\mathrm{BPH}$ patients by eviprostat.
OP-068 activity induced by acetic acid in conscious rats

\section{筑波大学大学院生命環境科学研究科"), グラクソスミスク ライン株式会社 ${ }^{2}$}

水戸部 学 ${ }^{1.2)}$, 井上 宏高 ${ }^{2)}$, 木下 美祢 ${ }^{2)}$, 深水 昭吉 ${ }^{11}$

Animal models that closely resemble the pathophysiology of human overactive bladder are important for evaluating novel therapeutics to treat the disorder. We established a non-invasive hyperactive bladder model that is sensitive to anti-muscarinic drugs and without bladder inflammation. Acetic acid solution was infused into the bladder for $5 \mathrm{~min}$ via the urethral orifice without any surgical procedures. As the results, infusion of a $0.5 \%$ acetic acid solution caused a significant increase in voiding frequency $(\mathrm{VF})$ without influencing total urine volume or inducing significant histopathological inflammatory alterations in the bladder urothelium. Oral administration of oxybutynin ( 3 and $10 \mathrm{mg}$ / $\mathrm{kg}$ ) significantly ameliorated increases in VF induced by $0.5 \%$ acetic acid. In this study, the non-invasive rat urinary hyperactive bladder model indicated minimizes the secondary effects of experimental procedures such as surgical operations and anesthesia on bladder function and is sensitive to oxybutynin. Thus, the model may be useful for investigating novel therapeutics for $\mathrm{OAB}$ treatment. 